\title{
Biochemical Genetics
}

National Cancer Institute

\section{Source}

National Cancer Institute. Biochemical Genetics. NCI Thesaurus. Code C16626.

The science concerned with the chemical and physical nature of genes and the genome. 